\title{
Analisis Mutu Layanan Instalasi Rawat Inap Menggunakan Metode Servqual - Fuzzy Dalam Upaya Meningkatkan Mutu Layanan Jasa Kesehatan di RS PBA Bandar Lampung
}

\author{
Emy Khikmawati' ${ }^{1}$, Heri Wibowo ${ }^{2}$, Zulkarnain Farla ${ }^{3}$ \\ Program Studi Teknik Industri Universitas Malahayati Bandar Lampung \\ Jl. Pramuka No.27 Kemiling Bandar Lampung, Indonesia \\ Email : emy_khikmawati@yahoo.com, heriwibowo_ti@yahoo.co.id
}

\begin{abstract}
ABSTRAK
Setiap pasien mengharap mendapatkan service yang inginkan. Hal ini, bila tidak direspon cepat baik oleh penyedia pelayanan, berakibat turunnya minat konsumen datang menggunakan jasa pelayanan rumah sakit. Permasalahan tersebut menjadi latar penelitian, dengan tujuan mengetahui tingkat kualitas layanan pada Instalasi Rawat Inap berdasarkan besarnya gap yang terjadi antara persepsi dan harapan dengan mengacu pada lima dimensi kualitas layanan (servqual) yaitu tangibles, reliability, responsiveness, assurance, empathy. Penelitian menggunakan survey dan kuesioner kemudian diolah menggunakan uji validitas dan reliabilitas. Metode pendekatan menggunakan Service Quality yang diintegrasikan dengan metode fuzzy, sehingga diperoleh hasil yang mampu mengakomodasikan ketidakpastian dan ketidaktepatan penilaian seseorang yang bersifat kualitatif. Responden 51 orang, semuanya merupakan pasien rawat inap kelas III yang menerima perawatan lebih dari 24 jam dengan maksud untuk mengetahui tingkat layanan yang diberikan pihak Rumah Sakit. Hasil menunjukkan kinerja layanan yang diberikan rumah sakit kepada pasien, terdapat beberapa atribut kinerja masih harus diperbaiki dan ditingkatkan kualitas layanan.
\end{abstract}

Kata kunci : Mutu Layanan, Dimensi Servqual, Fuzzy (Triangular Fuzzy Number).

\section{Pendahuluan}

RSPBA menyediakan bentuk pelayanan kesehatan, namun belum cukup memberikan hasil, karena kurang memperhatikan aspek pelayanannya. Keinginan pasien belum tentu sama dengan apa yang dimaksud dan dipahami oleh pihak rumah sakit. Informasi dari pasien tersebut digunakan untuk meningkatkan kualitas pelayanan dengan menentukan prioritas perbaikan kualitas jasa yang semestinya didahulukan. Kondisi tersebut, perlu diadakan penelitian tingkat kepuasan pasien pengguna layanan instalasi rawat inap terhadap kualitas jasa yang diberikan, sehingga tidak timbul suatu gap antara pelayanan yang dirasakan (persepsi) dan harapan (ekspektasi) suatu pasien terhadap kualitas layanan yang diterimanya. Bagaimana upaya RSBA untuk meningkatkan kualitas layanan sehingga dapat memenuhi kepuasan pasiennya Tujuan penelitian menganalisa kualitas pelayanan instalasi rawat inap RSBA agar diketahui atribut-atribut apa saja yang menjadi penyebab ketidakpuasan pasien sehingga berakibat terjadinya penurunan jumlah pasien. Dan menentukan strategi perbaikan untuk meningkatkan kualitas pelayanan.

\section{Metode Penelitian}

Penelitian menggunakan survey dan kuesioner kemudian diolah menggunakan uji validitas dan reliabilitas.Metode yang digunakan adalah metode Service Quality
(Servqual) yang diintegrasikan dengan metode Fuzzy (Triangular Fuzzy Number), sehingga diperoleh hasil yang lebih mampu mengakomodasikan ketidakpastian dan ketidaktepatan dari penilaian sesorang yang bersifat kualitatif/subjektif. Kuesioner ini mengidentifikasikan persepsi dan harapan pasien terhadap kriteria kualitas pelayanan di RSBA. Uji validitas dilakukan untuk mengetahui sejauh mana suatu alat pengukur itu mengukur apa yang ingin diukur. Uji reliabilitas dilakukan untuk mengetahui konsistensi atau keajegan suatu alat pengukur di dalam mengukur gejala yang sama. Setelah uji, diperoleh bobot untuk tiap variabel kualitas, selanjutnya analisa analisis service quality (serqual) dan fuzzy TFNs, ini untuk tingkat kepuasan pasien (persepsi dan harapan) terhadap pelayanan, dengan cara menganalisa gap-gap yang terjadi untuk setiap atribut pelayanan, sehingga dapat direkomendasikan kepada rumah sakit mengenai atributatribut yang menjadi prioritas untuk diperbaiki atau ditingkatkan kualitas jasanya. Analisa dilakukan dengan menghitung nilai mean persepsi dan harapan untuk tiaptiap variabel, kemudian dihitung selisih antara nilai mean tersebut, yang merupakan gap dari tiap-tiap variabel.

\section{Hasil dan Pembahasan}

Hasil pengolahan Uji Validitas.

\begin{tabular}{|c|c|c|c|}
\hline Dimensi & Atribut & $\mathbf{r}_{\text {Hitung }}$ & $\mathbf{r}_{\text {Tabel }}$ \\
\hline
\end{tabular}



dalam Bidang Teknik Industri

\begin{tabular}{|c|c|c|c|c|}
\hline \multirow{8}{*}{$\begin{array}{l}\text { Tangibles } \\
\text { (bukti } \\
\text { langsung) } \\
\mathrm{X}_{1}\end{array}$} & $\mathrm{X}_{11}$ & 0,725 & 0,233 & Valid \\
\hline & $\mathrm{X}_{12}$ & 0,678 & 0,233 & Valid \\
\hline & $X_{13}$ & 0,735 & 0,233 & Valid \\
\hline & $\mathrm{X}_{14}$ & 0,752 & 0,233 & Valid \\
\hline & $X_{15}$ & 0,652 & 0,233 & Valid \\
\hline & $X_{16}$ & 0,433 & 0,233 & Valid \\
\hline & $X_{17}$ & 0,463 & 0,233 & Valid \\
\hline & $\mathrm{X}_{18}$ & 0,584 & 0,233 & Valid \\
\hline \multirow{4}{*}{$\begin{array}{l}\text { Reliability } \\
\text { (keandalan } \\
\text { ) } \\
\mathrm{X}_{2}\end{array}$} & $X_{21}$ & 0,919 & 0,233 & Valid \\
\hline & $X_{22}$ & 0,823 & 0,233 & Valid \\
\hline & $X_{23}$ & 0,724 & 0,233 & Valid \\
\hline & $X_{24}$ & 0,584 & 0,233 & Valid \\
\hline \multirow{3}{*}{$\begin{array}{l}\text { Responsiv } \\
\text { eness } \\
\text { (daya } \\
\text { tanggap) } \\
\mathrm{X}_{3}\end{array}$} & $X_{31}$ & 0,688 & 0,233 & Valid \\
\hline & $X_{32}$ & 0,794 & 0,233 & Valid \\
\hline & $X_{33}$ & 0,663 & 0,233 & Valid \\
\hline \multirow{2}{*}{$\begin{array}{l}\text { Assurance } \\
\text { (Jaminan) } \\
\mathrm{X}_{4}\end{array}$} & $X_{41}$ & 0,687 & 0,233 & Valid \\
\hline & $\mathrm{X}_{42}$ & 0,880 & 0,233 & Valid \\
\hline \multirow{3}{*}{$\begin{array}{l}\text { Emphaty } \\
\text { (Kepedulia } \\
\mathrm{n} \text { ) } \\
\mathrm{X}_{5}\end{array}$} & $\mathrm{X}_{51}$ & 0,888 & 0,233 & Valid \\
\hline & $\mathrm{X}_{52}$ & 0,851 & 0,233 & Valid \\
\hline & $\mathrm{X}_{53}$ & 0,834 & 0,233 & Valid \\
\hline
\end{tabular}

\begin{tabular}{lllll}
\hline $\mathrm{X}_{5}$ & $\mathrm{X}_{52}$ & 0,911 & 0,276 & Valid \\
\cline { 2 - 5 } & $\mathrm{X}_{53}$ & 0,935 & 0,276 & Valid
\end{tabular}

Sumber: Hasil Perhitungan Kuesioner Penelitian (SPSS 16.00)

Hasil pengolahan uji reliabilitas

Tabel 3. Uji Reliabilitas Persepsi Responden

\begin{tabular}{lllll}
\hline Dimensi & Atribut & $\alpha_{\text {hitung }}$ & $\alpha_{\text {tabel }}$ & Kesimpulan \\
\hline Tangibles & $\mathrm{X}_{1}$ & 0,754 & 0,276 & Reliable \\
\hline Reliability & $\mathrm{X}_{2}$ & 0,769 & 0,276 & Reliable \\
\hline $\begin{array}{l}\text { Responsivene } \\
\text { ss }\end{array}$ & $\mathrm{X}_{3}$ & 0,525 & 0,276 & Cukup reliable \\
\hline Assurance & $\mathrm{X}_{4}$ & 0,385 & 0,276 & Agak Reliable \\
\hline Emphaty & $\mathrm{X}_{5}$ & 0,819 & 0,276 & Sangat reliable
\end{tabular}

Sumber: Hasil Perhitungan Kuesioner Penelitian (SPSS 16.00)

Tabel 4 Uji Reliabilitas Harapan Responden

\begin{tabular}{lllll}
\hline Dimensi & Atribut & $\alpha_{\text {hitung }}$ & $\alpha_{\text {tabel }}$ & Kesimpulan \\
\hline Tangibles & $\mathrm{X}_{1}$ & 0,744 & 0,276 & Reliable \\
\hline Reliability & $\mathrm{X}_{2}$ & 0,721 & 0,276 & Reliable \\
\hline $\begin{array}{l}\text { Responsivene } \\
\text { ss }\end{array}$ & $\mathrm{X}_{3}$ & 0,667 & 0,276 & Reliable \\
\hline Assurance & $\mathrm{X}_{4}$ & 0,402 & 0,276 & Cukup Reliable \\
\hline Emphaty & $\mathrm{X}_{5}$ & 0,863 & 0,276 & Sangat Reliable \\
\hline
\end{tabular}

Jumlah responden atau $\mathrm{N}$ sebesar 51, uji 1 sisi dengan signifikansi 5\%, maka $\mathrm{r}_{\text {tabel }}$ sebesar 0,233. (lihat tabel $\mathrm{r}$ produk moment pada Lampiran F). Kriteria suatu data dapat dinyatakan valid jika ( $\left.\mathrm{r}_{\text {Hitung }} \geq \mathrm{r}_{\text {Tabel }}\right)$.

Hasil uji validitas, seluruh instrumen (item-item pertanyaan) memenuhi kriteria validitas dengan $r$ Hitung $\geq \mathrm{r}$ Tabel, dengan demikian instrumen dinyatakan valid dan dapat diproses ke uji reliabilitas.

Tabel 2 Uji Validitas Harapan Responden

\begin{tabular}{lllll}
\hline Dimensi & Atribut & $\mathrm{r}_{\text {Hitung }}$ & $\mathrm{r}_{\text {Tabel }}$ & Kesimpulan \\
\hline & $\mathrm{X}_{11}$ & 0,588 & 0,276 & Valid \\
\cline { 2 - 5 } $\begin{array}{l}\text { Tangibles } \\
\text { (bukti } \\
\text { langsung) } \\
\mathrm{X}_{1}\end{array}$ & $\mathrm{X}_{12}$ & 0,679 & 0,276 & Valid \\
\cline { 2 - 5 } & $\mathrm{X}_{14}$ & 0,539 & 0,276 & Valid \\
\cline { 2 - 5 } & $\mathrm{X}_{15}$ & 0,747 & 0,276 & Valid \\
\cline { 2 - 5 } & $\mathrm{X}_{16}$ & 0,666 & 0,276 & Valid \\
\cline { 2 - 5 } & $\mathrm{X}_{17}$ & 0,466 & 0,276 & Valid \\
\cline { 2 - 5 } & $\mathrm{X}_{18}$ & 0,489 & 0,276 & Valid \\
\hline \multirow{2}{*}{$\begin{array}{l}\text { Reliability } \\
\text { (keandalan) }\end{array}$} & $\mathrm{X}_{21}$ & 0,645 & 0,276 & Valid \\
\cline { 2 - 5 } $\mathrm{X}_{2}$ & $\mathrm{X}_{22}$ & 0,723 & 0,276 & Valid \\
\cline { 2 - 5 } & $\mathrm{X}_{23}$ & 0,831 & 0,276 & Valid \\
\cline { 2 - 5 } & $\mathrm{X}_{24}$ & 0,759 & 0,276 & Valid \\
\hline $\begin{array}{l}\text { Responsivene } \\
\text { Ss (daya } \\
\text { tanggap) }\end{array}$ & $\mathrm{X}_{31}$ & 0,750 & 0,276 & Valid \\
\cline { 2 - 5 } $\mathrm{X}_{3}$ & $\mathrm{X}_{32}$ & 0,810 & 0,276 & Valid \\
\cline { 2 - 5 } $\begin{array}{l}\text { Assurance } \\
\text { (Jaminan) }\end{array}$ & $\mathrm{X}_{33}$ & 0,768 & 0,276 & Valid \\
\hline $\begin{array}{l}\text { Emphaty } \\
\text { (Kepedulian) }\end{array}$ & $\mathrm{X}_{41}$ & 0,749 & 0,276 & Valid \\
\cline { 2 - 5 } & $\mathrm{X}_{42}$ & 0,832 & 0,276 & Valid \\
\hline
\end{tabular}

Sumber: Hasil Perhitungan Kuesioner Penelitian (SPSS 16.00)

Besarnya reliabilitas yang paling baik adalah 1 dan yang paling buruk adalah 0. Semakin besar nilai yang diperoleh, maka semakin reliable atribut tersebut. Pada dasarnya, rata-rata seluruh instrumen memiliki tingkat reliabilitas yang cukup tinggi. Namun masih ada beberapa dimensi yang memiliki tingkat reliabilitas yang agak reliabel.

\section{Nilai Mean Persepsi dan Harapan Responden}

Hasil fuzzifikasi didapat dari penilaian persepsi dan harapan oleh responden dapat dihitung nilai mean sehingga didapatkan nilai rata-rata persepsi dan harapan responden. Nilai rata-rata ini berguna untuk memudahkan penganalisaan terhadap nilai fuzzy dari setiap atribut.

Tabel 5. Nilai Mean (Rata-Rata) Persepsi Responden (Fuzzy)

\begin{tabular}{llllll}
\hline \multirow{2}{*}{ No. } & Atribut & \multicolumn{3}{c}{ Fuzzy } & Batas \\
\cline { 3 - 5 } & & $\begin{array}{l}\text { Nilai } \\
\text { Bawah } \\
(\text { Low })\end{array}$ & $\begin{array}{l}\text { Tengah } \\
(\text { Crisp })\end{array}$ & $\begin{array}{l}\text { Batas } \\
\text { Atas } \\
(\boldsymbol{U} p)\end{array}$ & Defuzzifikasi \\
\hline 1 & $\mathrm{X}_{11}$ & 6,55 & 7,55 & 8,47 & 7,52 \\
\hline 2 & $\mathrm{X}_{12}$ & 6,08 & 7,08 & 8,04 & 7,07 \\
\hline 3 & $\mathrm{X}_{13}$ & 5,29 & 6,29 & 7,24 & 6,27 \\
\hline 4 & $\mathrm{X}_{14}$ & 5,84 & 6,84 & 7,84 & 6,84 \\
\hline 5 & $\mathrm{X}_{15}$ & 5,94 & 6,94 & 7,94 & 6,94 \\
\hline 6 & $\mathrm{X}_{16}$ & 5,27 & 6,27 & 7,24 & 6,26 \\
\hline 7 & $\mathrm{X}_{17}$ & 5,55 & 6,55 & 7,55 & 6,55 \\
\hline 8 & $\mathrm{X}_{18}$ & 6,10 & 7,10 & 8,06 & 7,08 \\
\hline
\end{tabular}




\begin{tabular}{llllll}
\hline 9 & $X_{21}$ & 5,39 & 6,39 & 7,35 & 6,38 \\
\hline 10 & $X_{22}$ & 5,31 & 6,31 & 7,31 & 6,31 \\
\hline 11 & $X_{23}$ & 5,96 & 6,96 & 7,94 & 6,95 \\
\hline 12 & $X_{24}$ & 6,08 & 7,08 & 8,06 & 7,07 \\
\hline 13 & $X_{31}$ & 5,92 & 6,92 & 7,90 & 6,92 \\
\hline 14 & $X_{32}$ & 5,49 & 6,49 & 7,47 & 6,48 \\
\hline 15 & $X_{33}$ & 5,86 & 6,86 & 7,86 & 6,86 \\
\hline 16 & $X_{41}$ & 5,98 & 6,98 & 7,98 & 6,98 \\
\hline 17 & $X_{42}$ & 5,75 & 6,75 & 7,73 & 6,74 \\
\hline 18 & $X_{51}$ & 4,92 & 5,92 & 6,92 & 5,92 \\
\hline 19 & $X_{52}$ & 5,51 & 6,51 & 7,49 & 6,50 \\
\hline 20 & $X_{53}$ & 5,00 & 6,00 & 6,98 & 5,99
\end{tabular}

Dari rata-rata penilaian persepsi responden pada Tabel 3.5, atribut-atribut pelayanan dapat diurutkan dari nilai yang tertinggi sampai yang terendah. Nilai yang terendah menunjukkan rendahnya performansi atribut pelayanan tersebut.

Tabel 6 Nilai Mean Persepsi Setelah diurutkan

\begin{tabular}{lll}
\hline No. & Atribut & Nilai Persepsi (fuzzy) \\
\hline 1 & $X_{11}$ & 7,52 \\
\hline 2 & $X_{18}$ & 7,08 \\
\hline 3 & $X_{12}$ & 7,07 \\
\hline 4 & $X_{24}$ & 7,07 \\
\hline 5 & $X_{41}$ & 6,98 \\
\hline 6 & $X_{23}$ & 6,95 \\
\hline 7 & $X_{15}$ & 6,94 \\
\hline 8 & $X_{31}$ & 6,92 \\
\hline 9 & $X_{33}$ & 6,86 \\
\hline 10 & $X_{14}$ & 6,84 \\
\hline 11 & $X_{42}$ & 6,74 \\
\hline 12 & $X_{17}$ & 6,55 \\
\hline 13 & $X_{52}$ & 6,50 \\
\hline 14 & $X_{32}$ & 6,48 \\
\hline 15 & $X_{21}$ & 6,38 \\
\hline 16 & $X_{22}$ & 6,31 \\
\hline 18 & $X_{13}$ & 6,27 \\
\hline 19 & $X_{16}$ & 6,26 \\
\hline 20 & $X_{53}$ & 5,99 \\
\hline
\end{tabular}

Perhitungan Mean Harapan Responden

Penilaian harapan yang telah diubah ke bentuk bilangan fuzzy dapat dihitung mean/rata-ratanya.

Tabel 7 Nilai Mean (Rata-Rata) Harapan Responden (Fuzzy)

\begin{tabular}{|c|c|c|c|c|c|}
\hline \multirow[b]{2}{*}{ No. } & \multirow[b]{2}{*}{ Atribut } & \multicolumn{3}{|l|}{ Fuzzy } & \multirow[b]{2}{*}{ Defuzzifikasi } \\
\hline & & $\begin{array}{l}\text { Batas } \\
\text { Bawah } \\
\text { (Low) }\end{array}$ & $\begin{array}{l}\text { Nilai } \\
\text { Tengah } \\
\text { (Crisp) }\end{array}$ & $\begin{array}{l}\text { Batas } \\
\text { Atas } \\
(U p p) \\
\end{array}$ & \\
\hline 1 & $X_{11}$ & 6,61 & 7,61 & 8,53 & 7,58 \\
\hline 2 & $X_{12}$ & 6,39 & 7,39 & 8,37 & 7,39 \\
\hline 3 & $X_{13}$ & 6,71 & 7,71 & 8,61 & 7,67 \\
\hline 4 & $\mathrm{X}_{14}$ & 6,39 & 7,39 & 8,39 & 7,39 \\
\hline 5 & $\mathrm{X}_{15}$ & 6,39 & 7,39 & 8,37 & 7,39 \\
\hline 6 & $\mathrm{X}_{16}$ & 6,49 & 7,49 & 8,45 & 7,48 \\
\hline 7 & $X_{17}$ & 6,45 & 7,45 & 8,43 & 7,44 \\
\hline 8 & $\mathrm{X}_{18}$ & 6,51 & 7,51 & 8,47 & 7,50 \\
\hline
\end{tabular}

\begin{tabular}{llllll}
\hline 9 & $\mathrm{X}_{21}$ & 6,33 & 7,33 & 8,33 & 7,33 \\
\hline 10 & $\mathrm{X}_{22}$ & 6,31 & 7,31 & 8,31 & 7,31 \\
\hline 11 & $\mathrm{X}_{23}$ & 6,27 & 7,27 & 8,27 & 7,27 \\
\hline 12 & $\mathrm{X}_{24}$ & 6,33 & 7,33 & 8,31 & 7,33 \\
\hline 13 & $\mathrm{X}_{31}$ & 6,33 & 7,33 & 8,33 & 7,33 \\
\hline 14 & $\mathrm{X}_{32}$ & 6,29 & 7,29 & 8,29 & 7,29 \\
\hline 15 & $\mathrm{X}_{33}$ & 6,31 & 7,31 & 8,29 & 7,31 \\
\hline 16 & $\mathrm{X}_{41}$ & 6,31 & 7,31 & 8,31 & 7,31 \\
\hline 17 & $\mathrm{X}_{42}$ & 6,35 & 7,35 & 8,31 & 7,34 \\
\hline 18 & $\mathrm{X}_{51}$ & 6,31 & 7,31 & 8,29 & 7,31 \\
\hline 19 & $\mathrm{X}_{52}$ & 6,20 & 7,20 & 8,20 & 7,20 \\
\hline 20 & $\mathrm{X}_{53}$ & 6,18 & 7,18 & 8,18 & 7,18 \\
\hline
\end{tabular}

Dari rata-rata penilaian harapan responden pada Tabel 3.7 atribut-atribut pelayanan dapat diurutkan dari nilai yang tertinggi sampai yang terendah. Nilai yang terendah menunjukkan rendahnya performansi atribut pelayanan tersebut.

Tabel 8 Nilai Mean Harapan Setelah diurutkan

\begin{tabular}{ccc}
\hline No. & Atribut & Nilai Harapan $(f u z z y)$ \\
\hline 1 & $X_{13}$ & 7,67 \\
\hline 2 & $X_{11}$ & 7,58 \\
\hline 3 & $X_{18}$ & 7,50 \\
\hline 4 & $X_{16}$ & 7,48 \\
\hline 5 & $X_{17}$ & 7,44 \\
\hline 6 & $X_{12}$ & 7,39 \\
\hline 7 & $X_{14}$ & 7,39 \\
\hline 8 & $X_{15}$ & 7,39 \\
\hline 9 & $X_{42}$ & 7,34 \\
\hline 10 & $X_{21}$ & 7,33 \\
\hline 11 & $X_{24}$ & 7,33 \\
\hline 12 & $X_{31}$ & 7,33 \\
\hline 13 & $X_{22}$ & 7,31 \\
\hline 14 & $X_{33}$ & 7,31 \\
\hline 15 & $X_{41}$ & 7,31 \\
\hline 16 & $X_{51}$ & 7,31 \\
\hline 17 & $X_{32}$ & 7,29 \\
\hline 18 & $X_{23}$ & 7,27 \\
\hline 19 & $X_{52}$ & 7,20 \\
\hline 20 & $X_{53}$ & 7,18 \\
\hline
\end{tabular}

\section{Perhitungan Nilai Servqual (Gap) Tanpa Bobot}

Setelah diperoleh nilai persepsi dan harapan responden (dalam bentuk fuzzy), maka dilakukan perhitungan nilai servqual tanpa bobot dengan rumus (Zeithaml, et. al., 1990) :

Nilai Servqual = Mean Persepsi Responden - Mean Harapan Responden

Untuk perhitungan nilai servqual pada atribut-atribut dalam tabel berikut :

Tabel 9. Nilai Servqual (Gap) Tanpa Bobot

\begin{tabular}{ccccc}
\hline No. & Atribut & $\begin{array}{c}\text { Defuzzifikasi } \\
\text { Persepsi }\end{array}$ & $\begin{array}{c}\text { Defuzzifikasi } \\
\text { Harapan }\end{array}$ & $\begin{array}{c}\text { Gap } \\
\text { (Nilai } \\
\text { Servqual) }\end{array}$ \\
\hline 1 & $\mathrm{X}_{11}$ & 7,52 & 7,58 & $-0,06$ \\
\hline 2 & $\mathrm{X}_{12}$ & 7,07 & 7,39 & $-0,32$ \\
\hline 3 & $\mathrm{X}_{13}$ & 6,27 & 7,67 & $-1,40$ \\
\hline 4 & $\mathrm{X}_{14}$ & 6,84 & 7,39 & $-0,55$ \\
\hline 5 & $\mathrm{X}_{15}$ & 6,94 & 7,39 & $-0,44$ \\
\hline 6 & $\mathrm{X}_{16}$ & 6,26 & 7,48 & $-1,22$ \\
\hline
\end{tabular}




\begin{tabular}{cllll}
\hline 7 & $\mathrm{X}_{17}$ & 6,55 & 7,44 & $-0,90$ \\
\hline 8 & $\mathrm{X}_{18}$ & 7,08 & 7,50 & $-0,41$ \\
\hline 9 & $\mathrm{X}_{21}$ & 6,38 & 7,33 & $-0,95$ \\
\hline 10 & $\mathrm{X}_{22}$ & 6,31 & 7,31 & $-1,00$ \\
\hline 11 & $\mathrm{X}_{23}$ & 6,95 & 7,27 & $-0,32$ \\
\hline 12 & $\mathrm{X}_{24}$ & 7,07 & 7,33 & $-0,25$ \\
\hline 13 & $\mathrm{X}_{31}$ & 6,92 & 7,33 & $-0,42$ \\
\hline 14 & $\mathrm{X}_{32}$ & 6,48 & 7,29 & $-0,81$ \\
\hline 15 & $\mathrm{X}_{33}$ & 6,86 & 7,31 & $-0,44$ \\
\hline 16 & $\mathrm{X}_{41}$ & 6,98 & 7,31 & $-0,33$ \\
\hline 17 & $\mathrm{X}_{42}$ & 6,74 & 7,34 & $-0,60$ \\
\hline 18 & $\mathrm{X}_{51}$ & 5,92 & 7,31 & $-1,39$ \\
\hline 19 & $\mathrm{X}_{52}$ & 6,50 & 7,20 & $-0,69$ \\
\hline 20 & $\mathrm{X}_{53}$ & 5,99 & 7,18 & $-1,18$ \\
\hline
\end{tabular}

Setelah didapatkan hasil nilai servqual tanpa bobot, maka nilai tersebut diurutkan mulai dari nilai gap negatif terbesar sampai negatif terkecil. Semakin besar negatif suatu atribut, berarti semakin rendah atribut tersebut dalam memenuhi kepuasan responden.

\section{Perhitungan Nilai Servqual (Gap) Terbobot}

Setelah dilakukan pembobotan pada setiap atribut pelayanan/jasa, maka dapat dihitung gap/nilai servqual terbobot dengan rumus :

Nilai Servqual (fuzzy)Tanpa Bobot X Bobot Untuk Setiap Atribut

Untuk perhitungan nilai servqual (Gap) terbobot, dalam tabel berikut :

Tabel 10. Nilai Servqual (Gap) Terbobot

\begin{tabular}{ccccc}
\hline No. & Atribut & $\begin{array}{c}\text { Nilai Servqual } \\
\text { (Gap) } \\
\text { Tanpa Bobot }\end{array}$ & Bobot & $\begin{array}{c}\text { Nilai Servqual } \\
\text { (Gap) } \\
\text { Terbobot }\end{array}$ \\
\hline 1 & $\mathrm{X}_{11}$ & $-0,06$ & 0,05 & $-0,003$ \\
\hline 2 & $\mathrm{X}_{12}$ & $-0,32$ & 0,05 & $-0,016$ \\
\hline 3 & $\mathrm{X}_{13}$ & $-1,40$ & 0,05 & $-0,07$ \\
\hline 4 & $\mathrm{X}_{14}$ & $-0,55$ & 0,05 & $-0,0275$ \\
\hline 5 & $\mathrm{X}_{15}$ & $-0,44$ & 0,05 & $-0,022$ \\
\hline 6 & $\mathrm{X}_{16}$ & $-1,22$ & 0,05 & $-0,061$ \\
\hline 7 & $\mathrm{X}_{17}$ & $-0,90$ & 0,05 & $-0,045$ \\
\hline 8 & $\mathrm{X}_{18}$ & $-0,41$ & 0,05 & $-0,0205$ \\
\hline 9 & $\mathrm{X}_{21}$ & $-0,95$ & 0,05 & $-0,0475$ \\
\hline 10 & $\mathrm{X}_{22}$ & $-1,00$ & 0,05 & $-0,05$ \\
\hline 11 & $\mathrm{X}_{23}$ & $-0,32$ & 0,05 & $-0,016$ \\
\hline 12 & $\mathrm{X}_{24}$ & $-0,25$ & 0,05 & $-0,0125$ \\
\hline 13 & $\mathrm{X}_{31}$ & $-0,42$ & 0,05 & $-0,021$ \\
\hline 14 & $\mathrm{X}_{32}$ & $-0,81$ & 0,05 & $-0,0405$ \\
\hline 15 & $\mathrm{X}_{33}$ & $-0,44$ & 0,05 & $-0,022$ \\
\hline 16 & $\mathrm{X}_{41}$ & $-0,33$ & 0,05 & $-0,0165$ \\
\hline 17 & $\mathrm{X}_{42}$ & $-0,60$ & 0,05 & $-0,03$ \\
\hline 18 & $\mathrm{X}_{51}$ & $-1,39$ & 0,05 & $-0,0695$ \\
\hline 19 & $\mathrm{X}_{52}$ & $-0,69$ & 0,05 & $-0,0345$ \\
\hline 20 & $\mathrm{X}_{53}$ & $-1,18$ & 0,05 & $-0,059$ \\
\hline & & & &
\end{tabular}

Setelah didapatkan hasil nilai servqual terbobot, maka nilai tersebut diurutkan mulai dari nilai gap negatif terbesar sampai negatif terkecil. Semakin besar negatif suatu atribut, berarti semakin rendah atribut tersebut dalam memenuhi kepuasan responden.

\section{Analisis Persepsi Responden}

Nilai persepsi responden menunjukkan tingkat kualitas layanan yang diterimanya selama menggunakan jasa kesehatan Instalasi Rawat Inap. Dari nilai mean persepsi dalam pengolahan data diketahui bahwa atribut kemampuan dokter dan perawat dalam berkomunikasi dengan pasien dan keluarganya $\left(\mathrm{X}_{51}\right)$ dan Pelayanan kepada semua pasien tanpa memandang status sosial $\left(\mathrm{X}_{53}\right)$ memiliki nilai terendah.

Tabel 11. Nilai Mean Persepsi Responden Terendah

\begin{tabular}{cccc}
\hline No. & Atribut & Keterangan & $\begin{array}{c}\text { Nilai Mean } \\
\text { Persepsi }\end{array}$ \\
\hline 1 & $\mathrm{X}_{51}$ & $\begin{array}{c}\text { Kemampuan dokter dan } \\
\text { perawat dalam berkomunikasi } \\
\text { dengan pasien dan keluarganya }\end{array}$ & 5,92 \\
\hline 2 & $\mathrm{X}_{53}$ & $\begin{array}{c}\text { Pelayanan kepada semua pasien } \\
\text { tanpa memandang status sosial }\end{array}$ & 5,99 \\
\hline
\end{tabular}

Nilai persepsi yang terendah menunjukkan rendahnya performansi pelayanan yang diterima responden. Informasi ini menandakan bahwa pihak Rumah Sakit (manajemen) sebaiknya memberikan perhatian lebih terhadap atribut pelayanan tersebut tanpa mengabaikan.

\section{Analisis Harapan Responden}

Nilai harapan responden menunjukkan tingkat keinginan responden terhadap pelayanan yang seharusnya diberikan oleh Insatalasi Rawat Inap. Nilai harapan yang tertinggi adalah harapan atribut kenyamanan ruang perawatan $\left(\mathrm{X}_{13}\right)$ serta Kebersihan ruang perawatan $\left(\mathrm{X}_{11}\right)$. Hal ini menunjukkan bahwa responden sangat ingin atribut ini diutamakan kualitas jasanya.

\begin{tabular}{|c|c|c|c|}
\hline No. & Atribut & Keterangan & $\begin{array}{c}\text { Nilai Mean } \\
\text { Persepsi }\end{array}$ \\
\hline 1 & $\mathrm{X}_{13}$ & Kenyamanan ruang perawatan & 7,67 \\
\hline 2 & $X_{11}$ & Kebersihan ruang perawatan & 7,58 \\
\hline
\end{tabular}

\section{Analisis Servqual (Gap) Tanpa Bobot}

Analisis ini dilakukan untuk mengetahui seberapa besar gap ( kesenjangan) yang terjadi antara nilai persepsi dan nilai harapan responden dan untuk mengetahui tingkat kepuasan responden, atribut yang memiliki gap terbesar adalah atribut kenyamanan ruang perawatan $\left(\mathrm{X}_{13}\right)$. Nilai ini menunjukkan bahwa terjadi kesenjangan yang paling besar antara persepsi dan harapan responden terhadap atribut ini. Harapan responden sangat tinggi $(7,67)$ pada atribut ini, sedangkan kenyataan yang telah diterima tidak terlalu tinggi $(6,27)$. sehingga timbulah kesenjangan yang paling besar terhadap nilai atribut ini. 
Tabel 13. Nilai Servqual Tanpa Bobot Dengan Gap Terbesar

\begin{tabular}{|c|c|c|c|c|c|}
\hline $\begin{array}{c}\text { No } \\
\text {. }\end{array}$ & $\begin{array}{l}\text { Atri } \\
\text { but }\end{array}$ & Keterangan & $\begin{array}{l}\text { Nilai } \\
\text { Mean } \\
\text { Persep } \\
\text { si }\end{array}$ & $\begin{array}{c}\text { Nilai } \\
\text { Mean } \\
\text { Harapan }\end{array}$ & $\begin{array}{c}\text { Nilai } \\
\text { Servqual } \\
\text { (Gap) } \\
\text { Tanpa } \\
\text { Bobot }\end{array}$ \\
\hline 1 & $\mathrm{X}_{13}$ & $\begin{array}{c}\text { Kenyamanan } \\
\text { ruang } \\
\text { perawatan }\end{array}$ & 6,27 & 7,67 & $-1,40$ \\
\hline
\end{tabular}

Tabel 14. Nilai Servqual Tanpa Bobot Dengan Gap Terkecil

\begin{tabular}{cccccc}
\hline No & Atrib & Keterangan & $\begin{array}{c}\text { Nilai } \\
\text { Mean } \\
\text { Persepsi }\end{array}$ & $\begin{array}{c}\text { Nilai } \\
\text { Mean } \\
\text { Harapan }\end{array}$ & $\begin{array}{c}\text { Silai } \\
\text { Servqual } \\
\text { (Gap) } \\
\text { Tanpa } \\
\text { Bobot }\end{array}$ \\
\hline 1 & $\mathrm{X}_{11}$ & $\begin{array}{c}\text { Kebersihan } \\
\text { ruang } \\
\text { perawatan }\end{array}$ & 7,52 & 7,58 & $-0,06$ \\
\hline
\end{tabular}

Nilai gap terkecil terdapat pada atribut kebersihan ruang perawatan $\left(\mathrm{X}_{11}\right)$ dengan nilai gap $(-0,06)$. Nilai ini menunjukkan bahwa responden sudah cukup puas terhadap atribut ini karena kenyataan yang telah diterima oleh responden hampir memenuhi harapannya, dengan kata lain atribut ini tidak terlalu penting bagi responden untuk ditingkatkan kualitas jasanya namun harus tetap dipertahankan kualitasnya.

\section{Analisis Servqual (Gap) Terbobot}

Nilai servqual yang telah didapatkan dari pencarian gap antara persepsi dan harapan responden harus dikalikan dengan nilai bobot tiap-tiap atribut sehingga akan didapatkan nilai servqual terbobot. Nilai servqual terbobot inilah yang akan digunakan sebagai acuan untuk melakukan perbaikan atau peningkatan kualitas jasa berdasarkan prioritas perbaikannya.

Tabel 15. Nilai Servqual (Gap) Terbobot Terbesar Dan Alternatif Solusi Perbaikannya

\begin{tabular}{|c|c|c|c|c|}
\hline No. & Atribut & Keterangan & $\begin{array}{c}\text { Nilai } \\
\text { Servqua } \\
l(\text { Gap) } \\
\text { Terbob } \\
\text { ot }\end{array}$ & $\begin{array}{l}\text { Alternatif Solusi } \\
\text { Perbaikan }\end{array}$ \\
\hline 1 & $X_{13}$ & $\begin{array}{l}\text { Kenyamanan } \\
\text { ruang } \\
\text { perawatan }\end{array}$ & $-0,07$ & 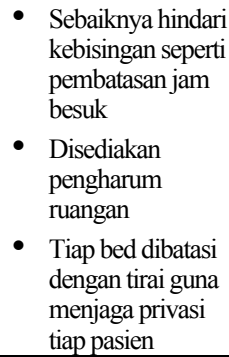 \\
\hline 2 & $\mathrm{X}_{51}$ & $\begin{array}{l}\text { Kemampuan } \\
\text { dokter dan } \\
\text { perawat } \\
\text { dalam } \\
\text { berkomunika } \\
\text { si dengan } \\
\text { pasien dan } \\
\text { keluarganya }\end{array}$ & $-0,0695$ & 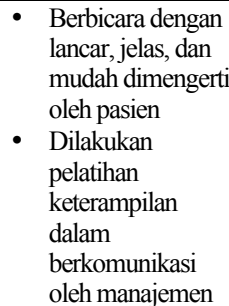 \\
\hline
\end{tabular}

\begin{tabular}{|c|c|c|c|c|}
\hline & & & & RSBAH \\
\hline 3 & $X_{22}$ & $\begin{array}{l}\text { Prosedur } \\
\text { pelayanan } \\
\text { yang mudah } \\
\text { dimengerti }\end{array}$ & $-0,05$ & $\begin{array}{l}\text { Tersedia prosedur } \\
\text { pelayanan tertulis } \\
\text { dan dijelaskan } \\
\text { prosedur tersebut } \\
\text { secara lisan } \\
\text { sehingga tidak } \\
\text { mempersulit } \\
\text { pasien } \\
\end{array}$ \\
\hline 4 & $X_{32}$ & $\begin{array}{l}\text { Kejelasan } \\
\text { dokter, } \\
\text { perawat dan } \\
\text { petugas } \\
\text { dalam } \\
\text { memberikan } \\
\text { informasi } \\
\text { yang } \\
\text { dibutuhkan } \\
\text { pasien }\end{array}$ & $-0,0405$ & $\begin{array}{l}\text { Dokter, perawat } \\
\text { dan petugas } \\
\text { berbicara dengan } \\
\text { jelas dan lancar } \\
\text { sehingga mudah } \\
\text { dimengerti oleh } \\
\text { pasien } \\
\text { Informasi yag } \\
\text { diberikan tidak } \\
\text { membingungkan } \\
\text { atau berbelat-belit }\end{array}$ \\
\hline 5 & $X_{42}$ & $\begin{array}{l}\text { Kesopanan } \\
\text { dan } \\
\text { keramahan } \\
\text { dokter dan } \\
\text { perawat saat } \\
\text { bertugas }\end{array}$ & $-0,03$ & $\begin{array}{l}\text { Bersikap sopan } \\
\text { dan ramah baik } \\
\text { dokter maupun } \\
\text { perawat sehingga } \\
\text { pasien merasa } \\
\text { nyaman di rumah } \\
\text { sakit tersebut } \\
\text { Baik dokter } \\
\text { maupun perawat } \\
\text { sebaiknya } \\
\text { bersabar dan } \\
\text { tersenyum dalam } \\
\text { menghadapi } \\
\text { pasien } \\
\text { Di rumah sakit } \\
\text { disediakan kotak } \\
\text { komplain untuk } \\
\text { pasien khusus } \\
\text { kepada } \\
\text { dokter/perawat } \\
\text { yang tidak bisa } \\
\text { bersikap ramah } \\
\text { kepada pasien } \\
\text { sehingga pihak } \\
\text { rumah sakit bisa } \\
\text { menegur } \\
\end{array}$ \\
\hline
\end{tabular}

Nilai servqual terbobot yang paling besar gap/kesenjangannya (sesuai dengan masing-masing dimensi) terdapat pada atribut Kenyamanan ruang perawatan $\left(\mathrm{X}_{13}\right)$, Kemampuan dokter dan perawat dalam berkomunikasi dengan pasien dan keluarganya $\left(\mathrm{X}_{51}\right)$, Prosedur pelayanan yang mudah dimengerti $\left(\mathrm{X}_{22}\right)$, Kejelasan dokter, perawat dan petugas dalam memberikan informasi yang dibutuhkan pasien $\left(\mathrm{X}_{32}\right)$ Kesopanan dan keramahan dokter dan perawat saat bertugas $\left(\mathrm{X}_{42}\right)$. Nilai tersebut menunjukkan bahwa atribut-atribut tersebut menjadi prioritas untuk diperbaiki atau ditingkatkan kualitas jasanya karena atribut-atribut tersebut sangat penting untuk memenuhi kepuasan responden.

Peningkatan kualitas jasa juga harus dilakukan pada atribut - atribut lain, karena dari hasil perhitungan servqual terbobot dapat diketahui bahwa atribut - atribut lainnya juga memiliki nilai negatif. Nilai negatif tersebut berarti pelayanan yang diberikan oleh Insatalasi Rawat 
Inap (IRNA) RSBAH Bandarlampung selama ini masih belum mampu memenuhi harapan responden.

Peningkatan layanan ini sangat diperlukan agar Instalasi Rawat Inap tidak kehilangan responden yang masih setia dan diharapkan mampu meningkatkan kembali jumlah pasiennya. Peningkatan kualitas jasa kesehatan ini juga bertujuan untuk memenangkan persaingan usaha dengan Insatalasi Rawat Inap.

\section{Kesimpulan}

Dari hasil penelitian dapat disimpulkan Keseluruhan kriteria pelayanan mempunyai nilai Gap yang negatif ini menunjukkan pihak Rumah Sakit belum mampu memenuhi kepuasan pengguna jasanya, karena itu harus lebih diperhatikan mutu layanan yang diberikan. Kriteria pelayanan yang memiliki nilai Gap negatif terkecil adalah "Kebersihan ruang perawatan", kriteria ini hampir memenuhi kepuasan pasien meskipun begitu kriteria pelayanan ini masih tetap perlu diperbaiki. Untuk kriteria pelayanan yang memiliki nilai Gap negatif terbesar adalah "kenyamanan ruang perawatan", kriteria ini belum memenuhi kepuasan pasien sehingga menjadi prioritas utama untuk diperbaiki.

\section{Daftar Pustaka}

[1] Aditama, Tjandra Yoga. 2003. Administrasi Rumah Sakit. Jakarta : Universitas Indonesia (UI-Press). Chan, L.K., Kao, H.P., Ng, A., and $\mathrm{Wu}$, M.L., 1999. International Journal Production Research. Vol. 37, No. 11, Halaman 2499 - 2158.

[2] Kotler, Philip. 2000. Manajemen Pemasaran. Jakarta : PT. Prehallindo.

[3] Kusumadewi, Sri. 2002. Analisis Dan Desain Sistem Fuzzy. Yogyakarta : Graha Ilmu.

[4] Kusumadewi, Sri dan Purnomo, Hari. 2010. Aplikasi Logika Fuzzy Untuk Pendukung Keputusan Edisi 2. Yogyakarta : Graha Ilmu.

[5] Mudie, Peter and Angela Cottam. 1993. The Management And Marketing Or Series. Oxford : Butterworth Heinemann Ltd., p.223.
[6] Nazir. 1998. Metode penelitian. Jakarta : Ghalia Indonesia.

[7] Olfa, Maria. 2005. "Peningkatan Kualitas Jasa Pelayanan Kesehatan Di Instalasi Rawat Inap Dengan Menggunakan Metode Servqual Fuzzy." Skripsi S1 Jurusan Teknik Industri Fakultas Teknologi Industri - Universitas Pembangunan Nasional "Veteran" Jawa Timur.

[8] Parasuraman, Valarie A. Zeithaml dan Leonard L. Berry. 1990. Delivering Quality Service Balancing Customer Perception And expectation. New York: The Free Press.

[9] Priyatno, Duwi. 2010. Paham Analisa Statistik Data Dengan SPSS. Yogyakarta : MediaKom.

[10] Santoso, Singgih dan Tjiptono, Fandy. 2002. Riset Pemasaran. Jakarta : PT. Elex Media Komputindo Kelompok Gramedia.

[11] Silvert, W., 1997. Journal Of Ecological Modelling. Vol. 96, Halaman 1- 10.

[12] Sugiyono. 2003. Statistika Untuk Penelitian. Bandung: CV. Alfabeta.

[13] Supranto, J. 1997. Pengukuran Tingkat Kepuasan Pelanggan.

[14] Tjiptono, Fandy. 2002. Manajemen Jasa. Yogyakarta : ANDI.

[15]Zeithaml, Valerie A. et al. 1991. Understanding, Measuring and Improving Service Quality In Brown, S. W., Gummeson, E., Edversson, B., Gustavsson, B. (Eds.), Service Quality Multidisciplinary and Multinational Perspective : 253-268, New York : Lexington Books. 